\title{
Efficacy of Macroeconomic Policies to Achieve Inclusive Growth: Evidence from Developing Countries
}

\author{
Zakia Batool $^{1}$ and Arshad Ali Bhatti ${ }^{2}$
}

\begin{abstract}
This paper aims to analyse the interactive role of fiscal and monetary policies in promoting inclusive growth. In this attempt, we use a panel data of 51 developing countries for the period 1995-2017 and employ state-of-the-art panel data estimation methods. The paper concludes that expansionary fiscal and monetary policies both affect economic inclusiveness in the developing region. However, it is observed that high expenditures in developing countries, which lead to debt crises, not only directly affect economic inclusiveness but also reduce the effectiveness of monetary policy. Therefore, the governments in these countries may consider cutting their spending. Thus, an increase in the money supply with a low to median level of government expenditure is a favourable policy option.
\end{abstract}

Keywords: Macroeconomic Policies, Inclusive Economic Growth, Panel Data JEL Classification: C33, E52, E62, F43, G2

\section{Introduction}

A report by $\mathrm{UNDP}^{3}$ reveals that household income inequality is rising in most of the developing world. In North Africa, Morocco is labelled as a country of wider wealth gap with a Gini coefficient at $40.3^{4}$ and 60 percent of the population attached to an informal sector that contributed to less than one-third of the GDP. For many decades, Asia was idealized by the world for having rapid growth. However, in the recent past, this region has been perceived as a region of increasing disparity between haves and have-nots. In China, one-third of the wealth is owned by one percent of the richest persons whereas only one percent of the total wealth is owned by 25 percent of the poorest ${ }^{5}$. In Pakistan, there is a big difference in the consumption pattern of the rich and the poor, that is, total consumption by the 18 million richest is 1.5 times the total consumption of the 72 million poorest. Also,

\footnotetext{
${ }^{1}$ Assistant Professor, Department of Economics, National University of Modern Languages, Islamabad, Pakistan.

${ }^{2}$ Assistant Professor, School of Economics, IIIE, International Islamic University, H-10, Islamabad, Pakistan.

Corresponding author's Email: arshad_bhatti@iiu.edu.pk

${ }^{3}$ United Nations Development Programme (UNDP). (2013). Humanity divided: Confronting inequality in developing countries.

${ }^{4}$ Report by OECD published on 11 July

${ }^{5} \mathrm{~A}$ report by Peking University published in 2015.
} 
the Pakistani youth bulge has become a ticking time bomb rather than a demographic dividend.

The early development theories of post-World War II have been focusing more on economic growth because they were of the view that fruits of growth process will gradually reach all individuals in the economy. The debates on economic development are now widely focusing on inclusive economic growth as an essential pillar of the development process because inclusive growth involves both participation and benefit-sharing. It ensures the participation of everyone in the economy by providing equal access to opportunities, thereby enabling every participant to reap their share of the growth. In short, inclusive growth ensures a growth pattern that leads the economy on a path of sustainable growth, and reduces unemployment, income inequality and poverty. Ranieri and Ramos (2013) are of the view that inclusiveness should be an essential part of growth strategies as it guarantees equal opportunities for the masses and protects markets and transitions in employment.

Regarding effectiveness of macroeconomic policies, the Great Depression was the most intriguing and complex economic event in the history of America and other countries of the world. In this context, Keynesians suggest that government intervention is much needed in times of low output level and high unemployment. Monetarists deny the proficient role of fiscal policy and believe in the active role of monetary policy in stabilizing the economy. Although inclusive growth has different dimensions - such as economic, social and environmental - this study, based on the above discussion, constructs an index of inclusive economic growth for developing countries and attempts to investigate an interactive role of monetary policy with fiscal policy in ensuring inclusive economic growth.

\section{Literature review}

The literary meaning of inclusive growth is related to the pace and pattern of economic growth. Stuart (2011), and Ranieri and Ramos (2013) attempt to define inclusive growth and are of the view that the notion of inclusive growth revolves around the concept of growth of the economy, poverty and inequality. Unequal distribution in income is a root cause of economic instability and creates economic and social unrest. Thus, such an economic and social chaos has a strong implication for social solidity and political stability, considered necessary for sustainable growth (Berg and Ostry, 2011). Ravallion and Chen (1997) examine that poverty depends on the distribution of income. And to ensure equal distribution of income, an equal access to economic opportunities is a necessary thing to make the participation of every individual in the economy possible. The slogan of 
inclusiveness of growth is "let's grow together" - that is, the benefits of economic growth should be shared equally.

As highlighted by Sen (1992), poverty and inequality are two different concepts that cannot replace each other. While focusing on the work of Sachs et al. (2004), which examines that in poor countries actual behaviour of the economy doesn't fall into line with the Solow model and that the poor economies have an intense tendency to be caught in different forms of poverty traps, Huang and Quibria (2013) draw attention to three types of traps namely, the low-productivity trap, Malthusian trap and saving trap. They suggest that foreign aid can play an effective role to save an economy from falling into these traps and encourage inclusive growth by enhancing human capacity to produce more. Studies such as White and Anderson (2001) are of the view that poverty and income inequality are linked with economic growth and owing to this association, a little change in the pattern of income distribution is capable of making a noticeable change in the poverty level. Smith (1776) explains that inequality causes poverty and that these two concepts are interlinked through private property and that the role of government, by protecting the property of the rich class, comes to reinforce inequality in society.

There are many studies that have highlighted the role of fiscal policy in ensuring inclusive growth (Alekhina and Ganelli, 2020; World Bank, 2020) whereas others have examined the potential of monetary instruments in making growth inclusive and sustainable (Adeleke et al. 2015; Pérez-Moreno et al. 2021) but we can't ignore the interaction of fiscal and monetary policies to achieve economic targets. Sprinkel (1963) suggests that to avoid risky economic fluctuations, both monetary and fiscal policies should be used. Wyplosz (1999), and Von-Hagen and Mundschent (2003) provide empirical evidence that monetary and fiscal policies move opposite to each other - that is, a tight monetary policy is needed in response to expansionary fiscal policy and vice versa. Sargent and Wallace (1984) explain that monetary policy can work efficiently only if fiscal policy in that economy is sustainable. On the other hand, Leeper (1991) explains that monetary and fiscal policy can be characterized as active and passive on the basis of inter-temporal constraint faced by the policy authority. Fiscal policy is known as passive policy if the policy authority makes changes in taxes in response to shocks to government debt. However, policy will be termed as active or forwardlooking if the spending and taxation decisions are made independent of the intertemporal budget constraint. Similarly, monetary policy is active if it follows the inflation targets autonomously whereas a backward-looking monetary policy focuses on setting interest rates in accordance with the fiscal policy objectives. 
Hilbers (2004) puts an effort in explaining the direct and indirect means through which fiscal policy can affect the monetary policy. The direct channel is through seigniorage. The resulting loose monetary policy fuels inflationary pressures, causing currency depreciation and thus affecting the balance of payments. Imposition of indirect taxes also causes inflation to level up and, by affecting a wage-price spiral, affects inflationary expectations. The indirect channel is through the expectation of outsized budget deficits that results in the requirement of large borrowings and hits the stability of financial markets. Thus, the monetary regime collapses. Therefore, coordination among fiscal and monetary authorities regarding their financial activities is required. However, Afonso et al. (2019) found a substitution relationship between fiscal and monetary policy and highlights the active role of monetary policy in case of high debts.

Overall, literature theoretically discusses the impact of macroeconomic policies on inclusive growth but lacks the empirical evidence. The composite effect of macroeconomic policies has also been ignored in the literature. This study takes up this issue and aims at developing a measure of inclusive growth for developing countries.

\section{Theoretical framework}

The idea of inclusive growth emerged about a decade ago. The early postworld war theories, for example Solow (1956) and Kuznets (1955), were primarily focused on growth process. The Solow model explains that poor countries grow faster and have the tendency to converge with the rich world. But this argument of the convergence was criticized heavily in the 1970s when most of the poor economies failed to converge with the developed world. World Bank (2009) explained the notion of inclusiveness in terms of the provision of equal opportunity to all to participate in the growth process. Although many studies discuss the nonincome dimensions of inclusive growth (Grosse et al., 2008; McKinley, 2010; Klasen, 2010; Rauniyar and Kanbur, 2010), this study sticks to the income dimension only.

According to the ADB (2014)'s definition there is difference between inclusive growth and pro-poor growth, where the former is the growth with declining income inequality and the later focuses on growth with fall in poverty therefore, for the measurement of inclusive economic growth this study considers income inequality only. Growth rate of per capita income is a basic component that helps in advancing inclusive growth because it is the root of the expansion of economic opportunities. The second measure of the economic dimension is the productive employment rate. Growth will be inclusive if maximum of the 
individuals living in an economy have the opportunity to participate in the growth process. Therefore, the growth of the economy needs to be paired with job creation. The third indicator of economic inclusive growth is income distribution. Barro (2000) and Keskin (2017), highlight that the impact of income inequality on growth is depressing in low-income countries while the case is opposite for the rich. This link between growth and income distribution provoked economists to think about inclusive growth. Thus, a growth will be inclusive if it improves income distribution. The fourth indicator is economic infrastructure. The participation of individuals in the growth process and the distribution of growth benefits to the masses require a well-established infrastructure of the economy. Inclusiveness of economic growth will reach an appropriate level if it causes maximum individuals to have an access to transportation and communication services. Individuals living in far flung areas are deprived of access to the market and other economic opportunities due to poor and costly transportation services. These individuals will have access to the market only if they have better access to economic infrastructure.

A detailed flow chart of how fiscal and monetary policy affects the indicators of inclusive economic growth is given in Figure 1. Fiscal policy through government expenditures and taxes has the capacity to affect economic activities, income distribution and infrastructure. Money supply through interest rate and credit supply channels affects the level of output and employment whereas through financial channels leads to an increase in capital accumulation and helps households to smoothen their consumption. Considering the interactive role of fiscal and monetary policy, Aghevli and Khan (1977) suggest that inflationary pressure created by increased money supply causes government expenditures to increase faster than revenue. Thus, causing a budget deficit that affects economic stability. On the other hand, to finance high-level government expenditures, developing countries heavily depend on printing of money that limits the monetary independence. Therefore, it is important to analyse the interactive role of these policies on inclusive economic growth.

Keeping in view the above theoretical link between macroeconomic policies and economic dimension of inclusive growth, we have the following functional form.

$\mathrm{IEG}=\mathrm{f}(\mathrm{F}, \mathrm{M}, \mathrm{Z})$

In the above function, IEG is index of inclusive economic growth, $\mathrm{F}$ is fiscal instrument and $\mathrm{M}$ is monetary instrument, however, $\mathrm{Z}$ is control variables. Since production is not possible without physical and human capital therefore, we have the following model. 
$\mathrm{IEG}=\mathrm{f}(\mathrm{F}, \mathrm{M}, \mathrm{K}, \mathrm{HCI})$

Studies show that institutional quality is also one of the factors that affect inclusive growth. Aslam et al (2020) suggest that in low- and middle-income countries, an established institutional structure results in increased inclusive growth. Whereas, in the era of globalisation, almost all countries are engaged in trading of goods and services therefore, trade is also taken as an exogenous variable that affects inclusive economic growth (Chongvilaivan, 2020). Hence, the functional form is as follows.

IEG $=\mathrm{f}(\mathrm{F}, \mathrm{M}, \mathrm{K}, \mathrm{HCI}$, Trade, IQ)

Figure 1: Impact of macroeconomic policies on inclusive economic growth

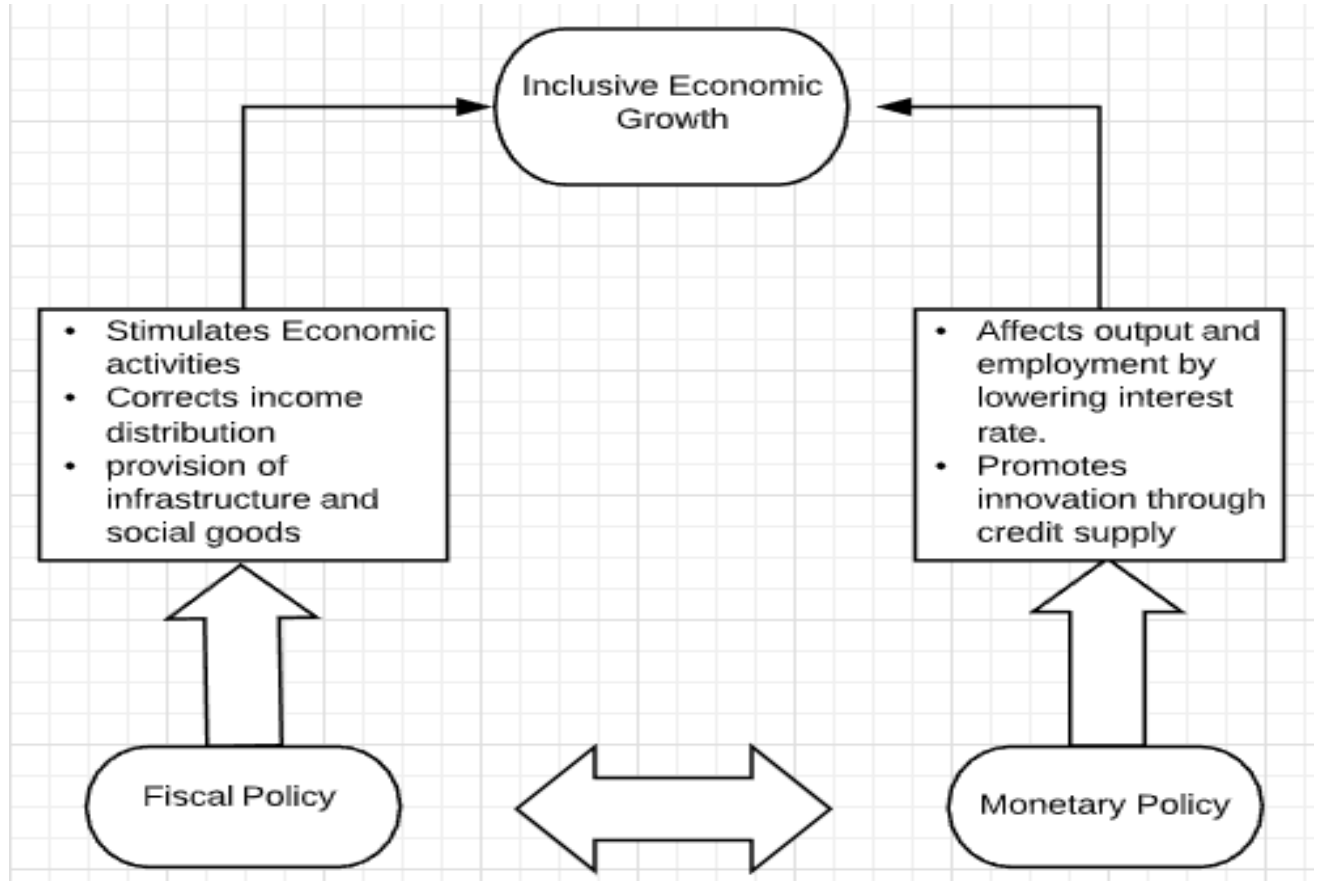

Source: Authors' construction

\subsection{The choice of econometric methodology}

To assess the impact of fiscal policy and monetary policy on inclusive economic growth, the following econometric model has been formulated.

$\mathrm{IEG}_{\mathrm{it}}=\alpha_{1}+\alpha_{2} \mathrm{M}_{\mathrm{it}}+\alpha_{3} \mathrm{~F}_{\mathrm{it}}+\alpha_{4} \mathrm{M}_{\mathrm{it}} * \mathrm{~F}_{\mathrm{it}}+\alpha_{5} \mathrm{Z}_{\mathrm{it}}+\mathrm{v}_{\mathrm{i}}+\omega_{\mathrm{t}}+\mathrm{u}_{\mathrm{it}} \ldots$

Where, IEG is Index of inclusive economic growth, $\mathrm{M}$ is money supply, $\mathrm{F}$ is fiscal policy indicator such as government expenditures $(\mathrm{G})$ and taxes (TX), and 
$\mathrm{Z}$ is the vector of control variables including physical capital stock $(\mathrm{K})$, human capital index (HCI), institutional quality (IQ) and openness (Trade). $\boldsymbol{u}$ is the error term and is assumed to be independently and identically distributed, that is, $\boldsymbol{u}_{\boldsymbol{i t}} \sim$ iid $\left(0, \sigma^{2}\right)$. The subscript $i$ is used to indicate the country and $\boldsymbol{t}$ shows the time period. $v_{i}$ and $\omega_{t}$ show the cross-country and cross-time effects. All the variables are taken in $\log$ form. The multiplicative interaction term $\left(\mathrm{M}^{*} \mathrm{~F}\right)$ is introduced in the model due to the fact that fiscal policy affects monetary policy. The effect of fiscal and monetary policy (from Equation 1) can thus be explained as follows.

$$
\begin{aligned}
& \frac{\partial I E G}{\partial M}=\alpha_{2}+\alpha_{4} F \\
& \frac{\partial I E G}{\partial F}=\alpha_{3}+\alpha_{4} M
\end{aligned}
$$

Equation 2 shows the conditional effect of money supply given different levels of fiscal variables. The parameter can take on various signs, for example, if both $\alpha_{2}$ and $\alpha_{4}$ have same signs then one can interpret that fiscal policy reinforces the effect of money supply on IEG, while if $\alpha_{2}$ is positive and $\alpha_{4}$ is negative, then fiscal policy reduces the positive effect of money supply on IEG and vice versa. In the same way, Equation 3 demonstrates the effect of fiscal policy conditional on different levels of money supply.

As our data is a panel of 51 developing countries ${ }^{6}$ for the period 1995-2017, we use state-of-the-art panel data estimation methods such as pooled estimation, fixed-effect and random-effect models. These methods incorporate countryspecific effects that may be important while analysing the panel data of developing countries, where some countries are growing at a faster rate as compared to others. A two-way fixed-effects model is used, incorporating country and time-specific intercepts. A fixed-effect model with a country-specific intercept is used to control unobserved heterogeneity while the heterogeneity is assumed to be constant over time and correlated with regressors. It is also assumed that heterogeneity is constant over the cross-sections as well.

In the random-effects model, it is assumed that cross-section or timespecific effects are not correlated with the explanatory variables. If the assumption of random-effects holds true, the parameter estimates from the random-effects model will be more efficient than that of the fixed-effects model. To determine whether to use random-effect or fixed-effect, the Hausman test is performed in this study. However, results of both models have been reported to check robustness. This study initially uses the fixed-effects and random-effects models, but to handle

${ }^{6}$ List of 51 developing countries is given in Table A1, Appendix. 
the issue of endogeneity and for robustness, a 2SLS model has also been used. To check the validity of instruments, Hansen's $J$ test, underlying the null hypothesis of "instruments are valid," is used.

\subsection{Description of variables}

To construct index of inclusive economic growth, principal component analysis (hereafter PCA) is employed, and the indicators used are per capita real income, employment rate, income distribution and infrastructure. Per capita real income is calculated by dividing a country's real Gross Domestic Product (hereafter GDP) by its population in a specific year. It signals an increase in productivity and also reflects prosperity. Data on per capita real GDP has been obtained from the World Development Indicators (hereafter WDI). To calculate productive employment, McKinley (2010) proposes many indicators. The share of workers employed in the industry is one of those indicators while others include the share of manufacturing and own-account workers. Due to unavailability of data for many countries, only the share of labourers in the industry has been used as a proxy that is assumed to partially measure productive employment as well. This data is retrieved from the International Labor Organization (hereafter ILO) database.

Gini coefficient is used as a proxy of income inequality. The value of the coefficient lies between 0 and 1 , where 0 shows perfect income equality and 1 shows perfect inequality. The data source of the Gini index is the Standardized World Income Inequality Database (hereafter SWIID). The fourth indicator of economic inclusive growth is physical infrastructure. With reference to McKinley (2010), the indicators of economic infrastructure include access to communication and electricity. For access to electricity, WDI's data on people with access to electricity as a percentage of the total population have been used. For communication, data on Mobile cellular subscription per 100 people and fixed telephone subscriptions per 100 people from WDI is used. The fiscal variables used in this study are tax revenue and government expenditures, both as a percentage of GDP. Tax revenue includes all the revenues that are collected from direct taxes such as income tax, profit tax, property tax, etc., and indirect taxes such as sales tax, custom duty tax, and excise duty tax, etc. and data is collected from WDI. For government expenditures, data on general government final consumption expenditure (\% of GDP) has been collected from the World Bank. It includes all the spending made for the purchase of goods and services, security and national defence, but not military expenditures. For money supply, the World Bank's data on broad money as percentage of GDP is used. 
For capital stock, gross fixed capital formation as a percentage of GDP is taken. As almost all developing countries are indulged in the trade of goods and services, this study makes an attempt to analyse the impact of trade openness on inclusive growth. Trade openness is calculated as the sum of imports and exports of goods and services as percentage of GDP. Since the 1980s, human capital has been considered as an important determinant of economic growth in the literature of growth (Mincer, 1981). Thus, its effect on inclusive growth is also analysed through this study. Data on the human capital index based on years of schooling and returns to education is obtained from Federal Reserve Economic Data (hereafter FRED) published by Research division of the Federal Reserve Bank of St. Louis. Institutional quality is also assumed to have a significant impact on inclusive growth because inclusive institutions will ensure inclusive growth. Data on institutional quality is gathered from International Country Risk Guide (ICRG) published by Political Risk Services.

To handle the problem of missing data, this study excludes the countries for which, over the required period, less than 25 percent data is available (Lin, Monga, and Standaert, 2019). This leaves us with only 51 developing countries. The index of economic infrastructure has been obtained by applying PCA on mobile phone and fixed telephone subscription per 100 people and proportion of people having access to electricity. This study has taken an inverse of the Gini index because an increase in the Gini index corresponds to higher inequality, affecting the inclusiveness of growth negatively. All the variables are normalized using a maxmin approach, which is how the values of each indicator are ensured to be between 0 and 100. Since PCA assumes a sufficient level of correlation among indicators, a pair wise correlation and Bonferroni-adjusted level of significance test is used. ${ }^{7}$

\section{Results and discussion}

\subsection{Graphical analysis}

As a part of preliminary analysis, scatter plots of dependent and independent variables have been plotted using locally-weighted smoothing to see the possible relationships between them. Figure 2 shows the relationship between economic inclusive growth and government expenditure.

${ }^{7}$ Author can provide the results of PCA on demand. 
Figure 2: Government expenditures and inclusive economic growth (IEG)

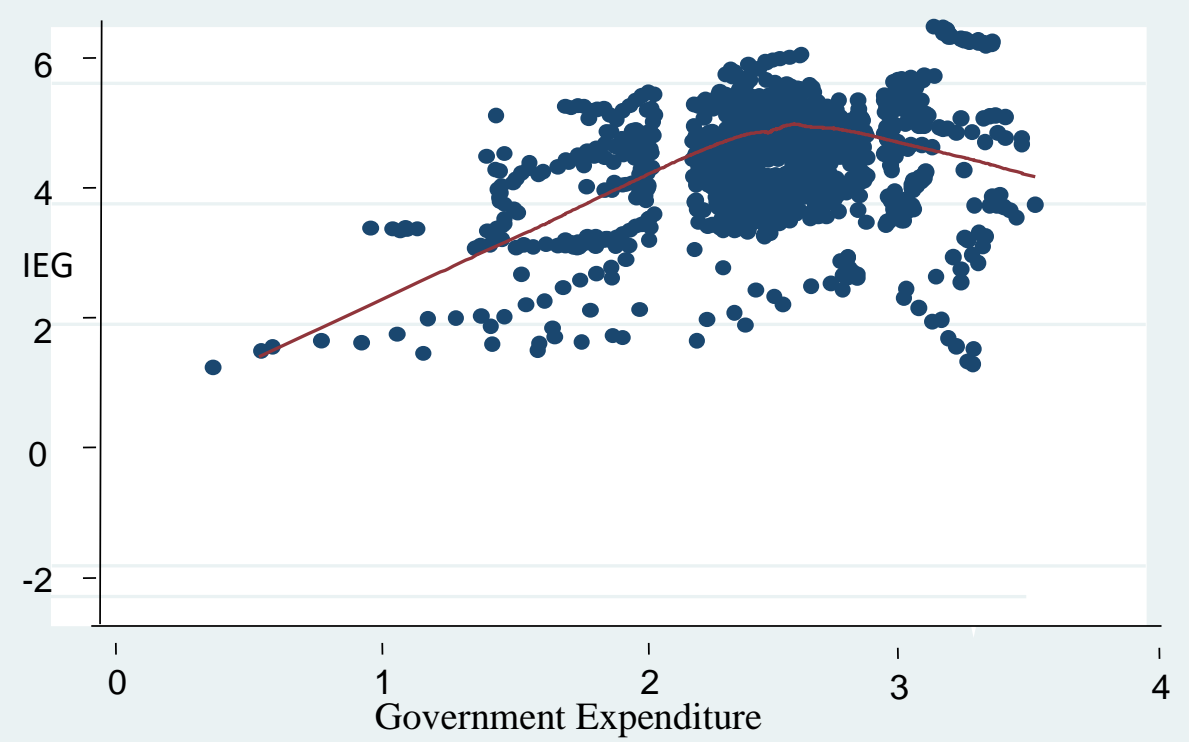

According to Figure 2, inclusiveness of the economy increases at initial levels of government expenditure whereas at higher levels it shows a negative relationship. Chu and Hemming (1991) explain that the composition of expenditure matters and productive expenditures are always growth-inducing. Rubinson (1977) and Ram (1986) found that, in the case of low-income countries, increasing government size stimulates growth. Barro (1990), Landau (1983) and Romer (1990) found that large shares of government consumption affect the growth rate of per-capita output negatively, but the relationship is positive for developing countries. Thus, countries having larger shares of government spending in their GDP than the optimal size are found to have less output and employment because it causes an increase in debt burden and crowds out private investment through interest rates.

Figure 3 shows a positive relationship between economic inclusiveness and tax revenue. This observation is in line with the study of Ofoegbu et al. (2016), which shows a positive and significant effect of tax revenue on economic development. Ola (2001) and Musgrave and Musgrave (2004) put in plain words that taxation mainly aims to resource mobilization and the distribution of wealth. It therefore, has an effect on income distribution as well as output, prices and employment levels. 
Figure 3: Tax revenue and inclusive economic growth (IEG)

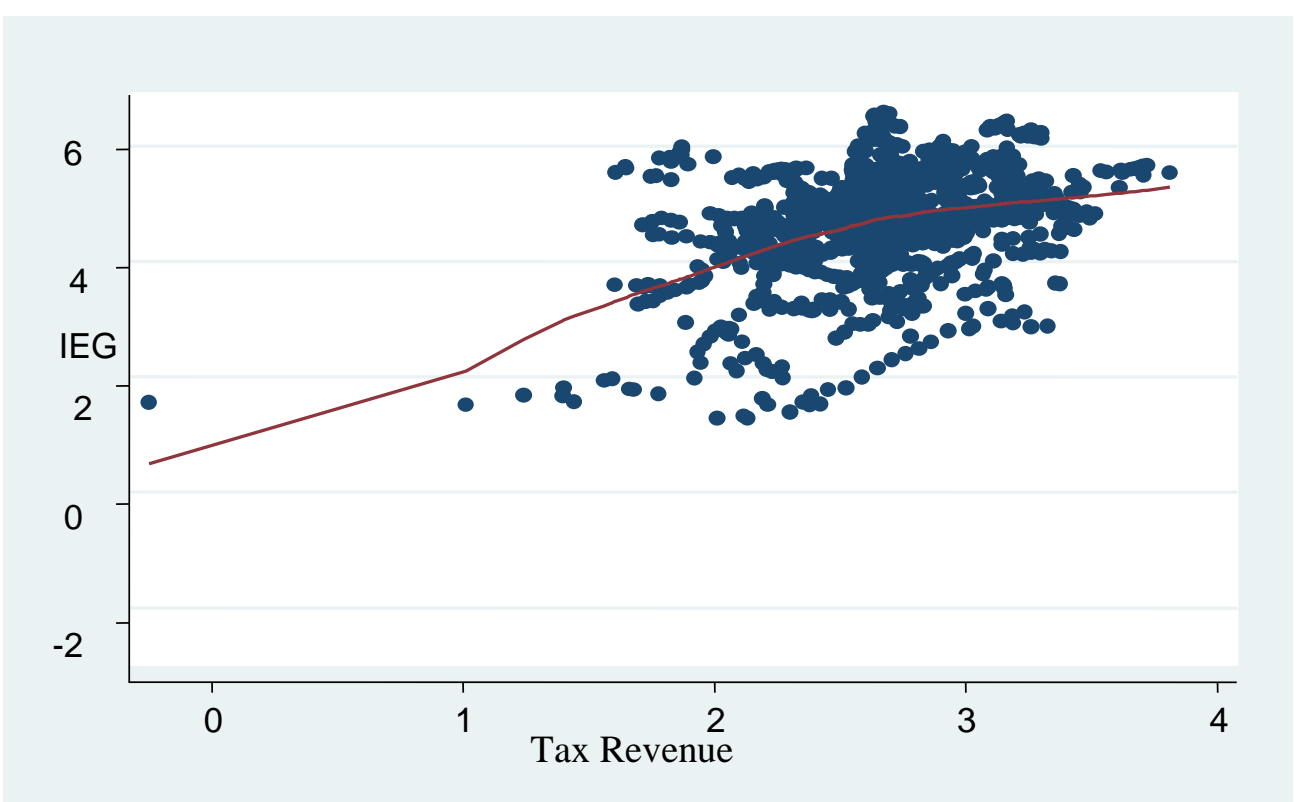

Figure 4: Money supply and inclusive economic growth (IEG)

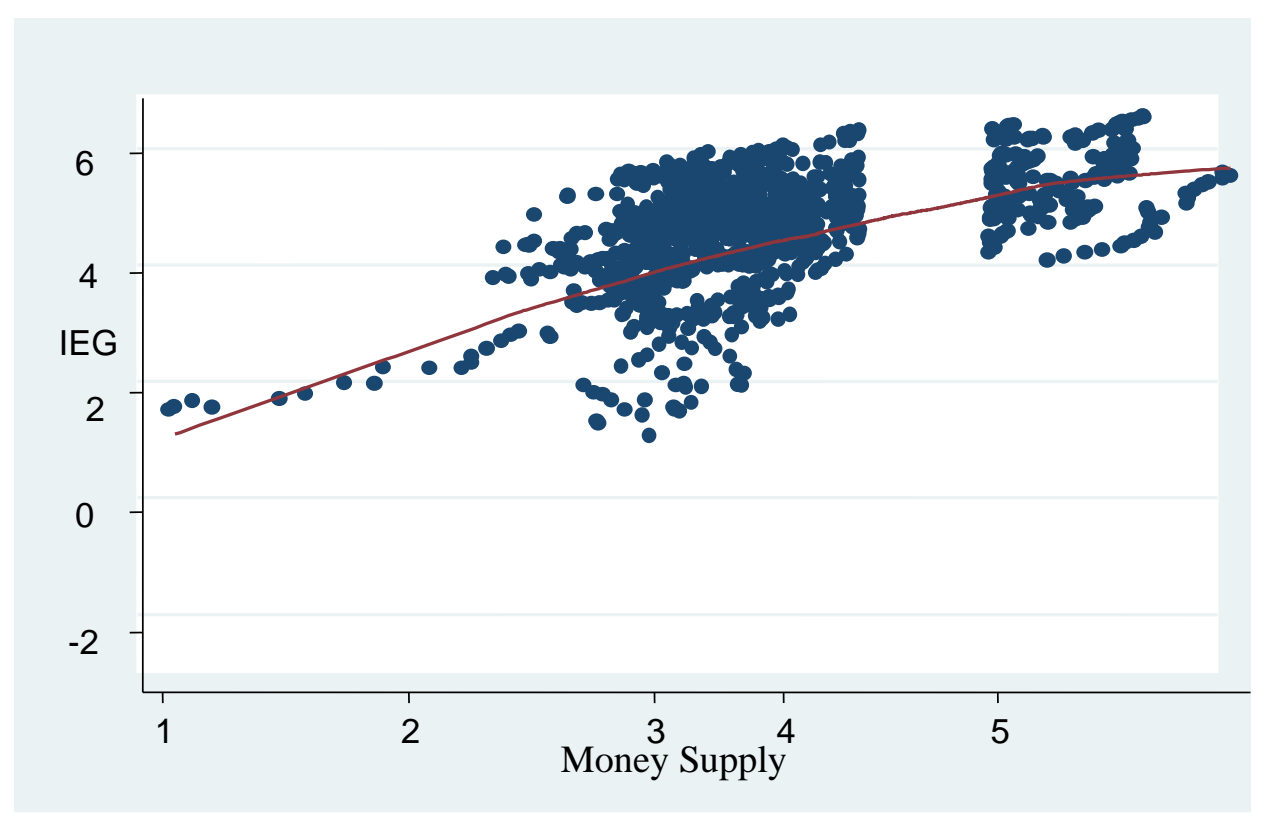

Figure 4 shows a positive link between economic inclusiveness and money supply, which supports the Monetarists' view. Many studies stress the fact that 
economic activities require a suitable level of supply of money in the economy (Friedman and Meiselman, 1963; Hanke, 1997). On the other hand, Ikhide and Alawode (1993) advise that a reduction in money supply causes an increase in the interest rate that in turn affects economic growth and employment negatively. Ogunmuyiwa and Ekone (2010) stress the fact that one of the reasons for a low level of growth and development in African countries is a low supply of money stock. Thus, money supply puts a positive impact on economic indicators.

\subsection{Regression Analysis}

Before analysing the interactive impact of fiscal and monetary policy on inclusive growth, this study initially analyses the effect of macroeconomic policies separately to investigate the effectiveness of one policy instrument in the absence of other policy. To find the most relevant factors for developing countries, this study uses a general-to-specific approach. This approach was introduced by Hendry (1995), beginning initially with an empirical analysis of a general model that assumes all possible regressors and reaches a complex model by reducing variables that express an insignificant impact on dependent variables. The validity of reductions is checked at each stage. Many researchers, including Hoover and Perez (1999), Ayeh and Lin (2011), Ciccone and Jarociński (2010), and Mohammed (2019), argue that this approach, based on $\boldsymbol{t}$ and $\boldsymbol{F}$ tests, ends up with the best model.

To analyse the impact of government expenditures on economic inclusive growth, the model considers the square of government expenditures because the graphical analysis in section 4 shows a quadratic link between government expenditure and inclusive growth. The results of Pooled OLS, FEM, REM and 2SLS are reported in Table 1a.

The linear term of government expenditure is significant and positive while the square term is negative and significant in all four models, confirming that an increase in government spending initially causes a positive impact by providing infrastructure facilities and subsidies etc. Higher expenditures put a negative impact on economic inclusive growth because increased government consumption expenditures require huge financing through heavy taxation and local and external debts. To analyse the conditional effect of government expenditure on economic inclusive growth, the derivative of the following equation has been taken with respect to government expenditure $(\mathrm{G})$ :

$$
\begin{aligned}
& I E G_{i t}=\alpha_{0}+\alpha_{1} G_{i t}+\alpha_{2} G_{i t}^{2}+\alpha_{3} Z_{i t}+u_{i t} \\
& \frac{\partial I E G}{\partial G}=\alpha_{1}+2 . \alpha_{2} G_{i t}
\end{aligned}
$$


Efficacy of Macroeconomic Policies to Achieve Inclusive Growth: Evidence from Developing Countries

Table 1a: Impact of government expenditures on inclusive economic growth

\begin{tabular}{|c|c|c|c|c|}
\hline Variables & POLS & FEM & REM & 2SLS \\
\hline $\mathrm{G}$ & $\begin{array}{c}1.838 * * * \\
(0.00)\end{array}$ & $\begin{array}{l}1.482 * * * \\
(0.002)\end{array}$ & $\begin{array}{l}1.489 * * * \\
(0.001)\end{array}$ & $\begin{array}{l}3.550 * * * \\
(0.00)\end{array}$ \\
\hline $\mathrm{G} 2$ & $\begin{array}{c}-0.539 * * * \\
(0.00)\end{array}$ & $\begin{array}{c}-0.292 * * * \\
(0.004)\end{array}$ & $\begin{array}{c}-0.292 * * * \\
(0.003)\end{array}$ & $\begin{array}{c}-0.673 * * * \\
(0.00)\end{array}$ \\
\hline $\mathrm{HCI}$ & $\begin{array}{l}2.477 * * * \\
(0.00)\end{array}$ & $\begin{array}{l}2.847 * * * \\
(0.00)\end{array}$ & $\begin{array}{l}2.837 * * * \\
(0.00)\end{array}$ & $\begin{array}{l}2.344 * * * \\
(0.00)\end{array}$ \\
\hline IQ & $\begin{array}{c}0.554 * * * \\
(0.00)\end{array}$ & $\begin{array}{l}0.218 * \\
(0.07)\end{array}$ & $\begin{array}{c}0.231 * * \\
(0.036)\end{array}$ & $\begin{array}{c}0.572 * * * \\
(0.00)\end{array}$ \\
\hline $\mathrm{K}$ & $\begin{array}{c}0.333 * * * \\
(0.00)\end{array}$ & $\begin{array}{c}0.270 * * * \\
(0.00)\end{array}$ & $\begin{array}{c}0.269 * * * \\
(0.00)\end{array}$ & $\begin{array}{c}0.358 * * * \\
(0.00)\end{array}$ \\
\hline Trade & $\begin{array}{c}-0.242^{* * *} * \\
(0.00)\end{array}$ & & & $\begin{array}{c}-2.357 * * * \\
(0.00)\end{array}$ \\
\hline Constant & $\begin{array}{c}-14.771 * * * \\
(0.00)\end{array}$ & $\begin{array}{c}-14.214^{* * * *} \\
(0.00)\end{array}$ & $\begin{array}{c}-14.240 * * * \\
(0.00)\end{array}$ & $\begin{array}{c}-15.191 * * * \\
(0.00)\end{array}$ \\
\hline No. of obs. & 1147 & 1147 & 1147 & 1096 \\
\hline $\begin{array}{l}\text { No. of countries } \\
\text { No. of instruments }\end{array}$ & 51 & 51 & 51 & $\begin{array}{c}51 \\
6\end{array}$ \\
\hline $\begin{array}{l}\text { R-Square } \\
\text { F-Stat } \\
\text { (p-value) }\end{array}$ & $\begin{array}{c}0.669 \\
296 * * * \\
(0.00) \\
\end{array}$ & $\begin{array}{c}0.639 \\
25.521 * * * \\
(0.00) \\
\end{array}$ & $\begin{array}{c}0.630 \\
138.45 * * * \\
(0.00) \\
\end{array}$ & $\begin{array}{c}0.681 \\
299.59 * * * \\
(0.00) \\
\end{array}$ \\
\hline Bruesch-Pagan LM & & & $\begin{array}{c}622.2 * * * * \\
(0.00)\end{array}$ & \\
\hline Hausman Test & & $\begin{array}{c}6.579 \\
(0.254) \\
\end{array}$ & & \\
\hline Durbin Wu-Hausman Test & & & & $\begin{array}{c}5.0381 * * \\
(0.011)\end{array}$ \\
\hline Hansen J Test & & & & $\begin{array}{c}0.315 \\
(0.574) \\
\end{array}$ \\
\hline
\end{tabular}

Notes: The dependent variable is an index of inclusive economic growth. G is government spending as a percentage of GDP, whereas G2 is the square of government spending as a percentage of GDP. HCI is human capital index, IQ is institutional quality, $\mathrm{K}$ is capital and Trade is trade openness. POLS is pooled OLS, FEM is fixed effects model, REM is random effect model. Bruesch-Pagan LM test suggests there exists random effects, Hausman test suggests that REM is preferable however, FEM is still used to see the effects of policies on dependent variable after controlling country specific effects, Durbin Wu-Hausman test suggests existence of endogeneity and Hansen-J test suggests that instruments are valid. P-values are given in parentheses. *,**,*** are 10,5 and 1 percent levels of significance respectively.

Table 1b: Non-linear Impact of Government Expenditures- using Table 1a

\begin{tabular}{|c|c|c|c|c|}
\hline $\mathbf{G}$ & POLS & FEM & REM & $2 \mathrm{SLS}$ \\
\hline \multirow[t]{2}{*}{$\mathrm{P} 25=2.337$} & $0.316^{* * *}$ & 0.116 & 0.123 & $0.406 * * *$ \\
\hline & $(0.000)$ & $(0.280)$ & $(0.240)$ & $(0.000)$ \\
\hline \multirow[t]{2}{*}{$\mathrm{P} 50=2.540$} & 0.097 & -0.003 & 0.004 & $0.133 * *$ \\
\hline & $(0.101)$ & $(0.982)$ & $(0.972)$ & $(0.010)$ \\
\hline \multirow[t]{2}{*}{$\mathrm{P} 75=2.760$} & $-0.141 * *$ & -0.131 & -0.124 & $-0.163 * *$ \\
\hline & $(0.059)$ & $(0.380)$ & $(0.391)$ & $(0.014)$ \\
\hline
\end{tabular}

Notes: As for Table 1. ***,**** are 1, 5 and 10 percent levels of significance respectively. P25, P50 and p75 are the $25^{\text {th }}$, $50^{\text {th }}$ and $75^{\text {th }}$ percentile values of $\mathrm{G}$ respectively.

In the above equation, $\mathrm{Z}$ is the vector of control variables. The derivative shows that the impact of G on IEG is nonlinear, and it is conditional on the levels of $\mathrm{G}$. Thus, it is calculated using different levels of government expenditures, that is, the $25^{\text {th }}, 50^{\text {th }}$ and $75^{\text {th }}$ percentiles. The results are shown in Table $1 \mathrm{~b}$. 
The POLS model shows that at lower values, government expenditures affect economic inclusiveness positively. The effect is insignificant at the median value whereas negative and significant at higher values. FEM and REM models show an insignificant effect of government expenditures, whereas the 2SLS model shows that at low levels the effect of government expenditure is 0.406 percent and significant, reducing to 0.133 percent as the government size increases. However, at higher levels, the impact of government expenditure has a negative impact on economic inclusive growth. This result is in accordance with Barro (1990), who suggests that after reaching a peak, an increase in government consumption expenditure results in a decline in economic activities, consequently causing a decline in employment. Armey (1995) also introduced an inverted U-shaped relationship between public expenditure and growth. Hajamini and Falahi (2014) too, conclude the existence of the "Barro" curve in developing countries.

Further, Table 1a shows that the impact of human capital on inclusive economic growth is positive and significant at $1 \%$ level. An increase in human capital increases economic growth by increasing the productivity of labourers and thus increases employment opportunities for them. It also helps to reduce income inequality based on Becker's (1962) view that the distribution of income depends on the distribution of individuals' ability, which in turn depends on human capital investment. Schultz (1963) also finds a positive impact of human capital on income distribution, while Fleisher, Li and Zhao (2010) find that human capital affects growth and its distribution positively as well. Capital stock also affects inclusive economic growth positively because an increase in investment in capital causes a positive effect on growth and helps to generate employment opportunities.

To ensure the property rights and proper functioning of the economic system, corruption-free and efficient institutions are required. Therefore, institutional quality too affects economic inclusive growth positively and significantly. This result is in accordance with the study of Nirola and Sahu (2019), which explains that the effectiveness of government expenditures in achieving their target depends on institutional quality. The impact of trade on economic inclusive growth is negative because the increase in imports hurts the local industries; the export products of developing countries cannot compete with the standards of international markets due to lack of technology (Meschi and Vivarelli, 2009). It also affects the income distributions negatively because a larger share of benefits of trade goes into the pockets of the rich class (Aradhyula, Rahman and Seenivasan, 2007). 
Table 2 presents the results of models explaining the role of tax revenue on economic inclusive growth. The results of POLS and 2SLS models show that tax revenue has a positive and significant impact on economic inclusive growth because when it comes to equality of income distribution and economic stabilization, tax revenue is a prima facie tool. The prime objective of tax collection is to finance government expenditures, such as infrastructure and welfare services, that help to achieve economic and social targets (Okpe, 2000). Tax revenue helps to generate employment opportunities, improve income distribution and stabilize the price level (Musgrave and Musgrave, 2004; Onoh, 2013). Thus, a moderate level of taxation helps developing economies to reduce the debt burden and encourages economic inclusiveness.

Table 2: Impact of tax revenue on inclusive economic growth

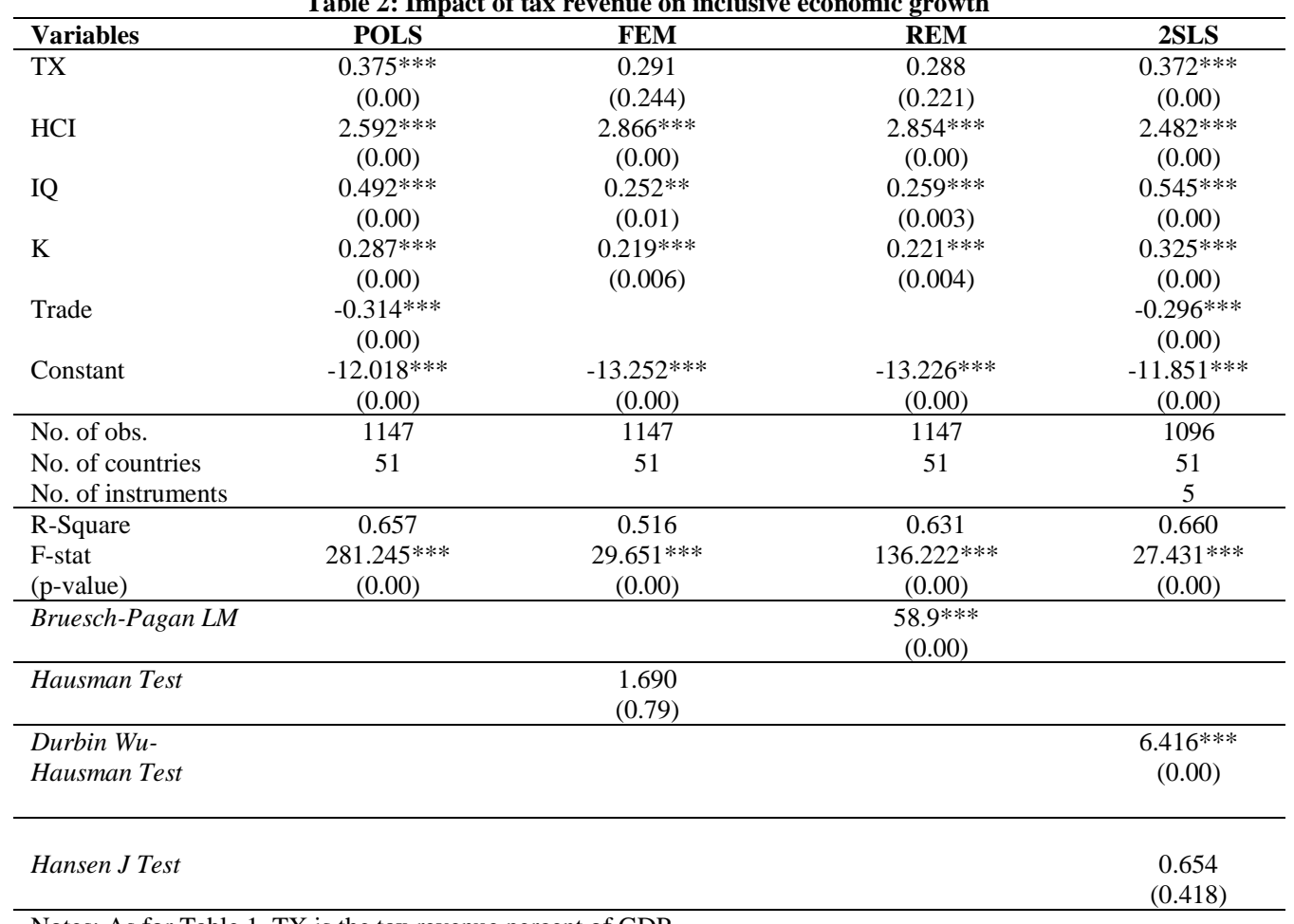

Notes: As for Table 1. TX is the tax revenue percent of GDP.

Turning to the impact of monetary policy on inclusive economic growth, Table 3 shows the impact of money supply on economic inclusiveness. An increase in money supply through the stimulation of aggregate demand affects the level of output, employment and income distribution. The increase in level of economic activity to decreased interest rate provokes many entrepreneurs to start business and expands the opportunity for maximum people to get the status of 'employed'. This 
result is in accordance with Lucas (1972) and Barro (1976), who are of the view that money supply affects economic activities significantly, if the change is unperceived. Through the inflation channel, the effect of monetary policy on income distribution is negative as per Taghizadeh-Hesary, Yoshino and Shimizu (2018), whereas studies like Romer and Romer (1998) are of the view that an increase in money supply by stabilizing aggregate demand creates a cyclical boom and improves income distribution.

Table 3: Impact of money supply on inclusive economic growth

\begin{tabular}{|c|c|c|c|c|}
\hline Variables & POLS & FEM & REM & 2SLS \\
\hline M & $\begin{array}{c}0.396 * * * \\
(0.00)\end{array}$ & $\begin{array}{c}0.257 * * \\
(0.037)\end{array}$ & $\begin{array}{c}0.262^{* *} \\
(0.019)\end{array}$ & $\begin{array}{c}0.380 * * * \\
(0.00)\end{array}$ \\
\hline $\mathrm{HCI}$ & $\begin{array}{c}2.444 * * * \\
(0.00)\end{array}$ & $\begin{array}{l}2.445^{* * * *} \\
(0.00)\end{array}$ & $\begin{array}{c}2.452 * * * \\
(0.00)\end{array}$ & $\begin{array}{c}2.339 * * * \\
(0.00)\end{array}$ \\
\hline IQ & $\begin{array}{c}0.487 * * * \\
(0.00)\end{array}$ & $\begin{array}{l}0.275^{* *} \\
(0.015)\end{array}$ & $\begin{array}{c}0.287 * * * \\
(0.006)\end{array}$ & $\begin{array}{c}0.450 * * * \\
(0.00)\end{array}$ \\
\hline K & & $\begin{array}{c}0.224 * * * \\
(0.005)\end{array}$ & $\begin{array}{l}0.22 * * * \\
(0.003)\end{array}$ & $\begin{array}{l}0.17^{*} \\
(0.07)\end{array}$ \\
\hline Trade & $\begin{array}{c}-0.199 * * * \\
(0.00)\end{array}$ & & & $\begin{array}{c}-0.188^{* * * *} \\
(0.00)\end{array}$ \\
\hline Constant & $\begin{array}{c}-11.296 * * * \\
(0.00) \\
\end{array}$ & $\begin{array}{c}-11.317 * * * \\
(0.00) \\
\end{array}$ & $\begin{array}{c}-11.416^{* * * *} \\
(0.00) \\
\end{array}$ & $\begin{array}{c}-11.069^{* * * *} \\
(0.00)\end{array}$ \\
\hline No. of obs. & 1147 & 1147 & 1147 & 1096 \\
\hline $\begin{array}{l}\text { No. of countries } \\
\text { No. of instruments }\end{array}$ & 51 & 51 & 51 & $\begin{array}{c}51 \\
4\end{array}$ \\
\hline R-Square & 0.675 & 0.518 & 0.661 & 0.700 \\
\hline $\begin{array}{l}\text { F-Stats } \\
\text { (p-value) }\end{array}$ & $\begin{array}{c}353.521 * * * \\
(0.00)\end{array}$ & $\begin{array}{c}27.059 * * * \\
(0.00)\end{array}$ & $\begin{array}{c}112.391 * * * \\
(0.00)\end{array}$ & $\begin{array}{c}353.200 * * * \\
(0.00)\end{array}$ \\
\hline Bruesch-Pagan LM & & & $\begin{array}{c}826.3^{* * * *} \\
(0.00)\end{array}$ & \\
\hline Hausman Test & & $\begin{array}{l}2.481 \\
(0.65) \\
\end{array}$ & & \\
\hline $\begin{array}{l}\text { Durbin Wu-Hausman } \\
\text { Test }\end{array}$ & & & & $\begin{array}{c}5.843^{* *} \\
(0.01) \\
\end{array}$ \\
\hline Hansen J & & & & $\begin{array}{c}0.495 \\
(0.481)\end{array}$ \\
\hline
\end{tabular}

Notes: As for Table 1. M is broad money percent of GDP.

The results in Table 4a show the interactive role of fiscal and monetary policy in promoting economic inclusiveness. In the equation given below, $\mathrm{Z}$ is the vector of control variables. To explore the effect of one policy given the other, the derivative of the model with respect to government expenditures and money supply is taken as follows:

$$
\begin{gathered}
I E G_{i t}=\beta_{0}+\beta_{1} M_{i t}+\beta_{2} G_{i t}+\beta_{3} G_{i t}^{2}+\beta_{4} M * G_{i t}+\beta_{5} M * G_{i t}^{2}+\beta_{6} Z_{i t}+u_{i t} \\
\frac{\partial I E G}{\partial M}=\beta_{1}+\beta_{4} G_{i t}+\beta_{5} \cdot G^{2}
\end{gathered}
$$


Efficacy of Macroeconomic Policies to Achieve Inclusive Growth: Evidence from Developing Countries

$$
\frac{\partial I E G}{\partial G}=\beta_{2}+2 \cdot \beta_{3} G_{i t}+\beta_{4} \cdot M_{i t}+2 \cdot \beta_{5} M * G_{i t}
$$

Table 4a: Interactive impact of money supply and government expenditures

\begin{tabular}{|c|c|c|c|c|}
\hline Variables & POLS & FEM & REM & 2SLS \\
\hline \multirow[t]{2}{*}{$\mathrm{M}$} & 0.592 & 0.082 & 0.061 & $1.811 *$ \\
\hline & $(0.36)$ & $(0.86)$ & $(0.899)$ & $(0.07)$ \\
\hline \multirow[t]{2}{*}{ G } & $3.562 *$ & 2.192 & 2.101 & $7.669 * *$ \\
\hline & $(0.08)$ & $(0.234)$ & $(0.264)$ & $(0.02)$ \\
\hline \multirow[t]{2}{*}{$\mathrm{G} 2$} & $-0.725 *$ & -0.617 & -0.594 & $-1.458 * *$ \\
\hline & $(0.10)$ & $(0.226)$ & $(0.252)$ & $(0.03)$ \\
\hline \multirow[t]{2}{*}{$\mathrm{M}^{*} \mathrm{G}$} & -0.231 & -0.138 & -0.108 & -1.100 \\
\hline & $(0.68)$ & $(0.78)$ & $(0.836)$ & $(0.19)$ \\
\hline \multirow[t]{2}{*}{$\mathrm{M}^{*} \mathrm{G} 2$} & 0.054 & 0.078 & 0.071 & 0.210 \\
\hline & $(0.64)$ & $(0.56)$ & $(0.606)$ & $(0.24)$ \\
\hline \multirow[t]{2}{*}{$\mathrm{HCI}$} & $2.279 * * *$ & $2.274 * * *$ & $2.283 * * *$ & $2.211 * * *$ \\
\hline & $(0.00)$ & $(0.00)$ & $(0.00)$ & $(0.00)$ \\
\hline \multirow{2}{*}{ IQ } & $0.383 * * *$ & $0.188 * *$ & $0.206^{* *}$ & $0.261 * * *$ \\
\hline & $(0.00)$ & $(0.04)$ & $(0.02)$ & $(0.00)$ \\
\hline \multirow[t]{2}{*}{ K } & $0.151 * * *$ & $0.238 * * *$ & $0.233 * * *$ & $0.239 * *$ \\
\hline & $(0.01)$ & $(0.00)$ & $(0.00)$ & $(0.01)$ \\
\hline \multirow[t]{2}{*}{ Trade } & $-0.233 * * *$ & & & $-0.250 * * *$ \\
\hline & $(0.00)$ & & & $(0.00)$ \\
\hline \multirow{2}{*}{ Constant } & $-14.398 * * *$ & $-11.510 * * *$ & $-11.577 * * *$ & $-19.290 * * *$ \\
\hline & $(0.00)$ & $(0.00)$ & $(0.00)$ & $(0.00)$ \\
\hline No. of obs. & 1147 & 1147 & 1147 & 947 \\
\hline No. of countries & 51 & 51 & 51 & 51 \\
\hline No. of instruments & & & & 9 \\
\hline R-Square & 0.703 & 0.553 & 0.661 & 0.719 \\
\hline F-Stats & 234.080 *** & $22.858 * * *$ & $112.388^{* * * *}$ & $199.259 * * *$ \\
\hline (p-value) & $(0.00)$ & $(0.00)$ & $(0.00)$ & $(0.00)$ \\
\hline \multirow{2}{*}{\multicolumn{2}{|c|}{ Bruesch-Pagan LM }} & & $455.3 * * *$ & \\
\hline & & & $(0.00)$ & \\
\hline \multirow{2}{*}{\multicolumn{2}{|c|}{$\begin{array}{l}\text { Hausman } \\
\text { Test }\end{array}$}} & 5.530 & & \\
\hline & & $(0.47)$ & & \\
\hline \multirow{2}{*}{\multicolumn{2}{|c|}{$\begin{array}{l}\text { Durbin Wu- } \\
\text { Hausman Test }\end{array}$}} & & & $8.612 * * *$ \\
\hline & & & & $(0.00)$ \\
\hline \multirow{2}{*}{\multicolumn{2}{|c|}{ Hansen J Test }} & & & 0.018 \\
\hline & & & & $(0.894)$ \\
\hline
\end{tabular}

Notes: As in Table 1. M is money supply, $\mathrm{M}^{*} \mathrm{G}$ is the interaction of money supply and government expenditures and $\mathrm{M} * \mathrm{G} 2$ is the interaction of money supply and square of government expenditures.

Table 4b: Impact of money supply at different levels of G- using Table 4a

\begin{tabular}{lcccc}
\hline $\mathbf{G}$ & POLS & FEM & REM & 2SLS \\
\hline P25=2.337 & $0.349 * * *$ & $0.187 * *$ & $0.196 * *$ & $0.370^{* * *}$ \\
& $(0.00)$ & $(0.04)$ & $(0.036)$ & $(0.000)$ \\
P50 $=2.540$ & $0.360^{* * *}$ & $0.237 * * *$ & $0.244^{* * *}$ & $0.350^{* * *}$ \\
& $(0.00)$ & $(0.01)$ & $(0.008)$ & $(0.00)$ \\
P75=2.760 & $0.368^{* * *}$ & $0.298^{* * *}$ & $0.303 * * *$ & $0.351 * *$ \\
& $(0.00)$ & $(0.01)$ & $(0.009)$ & $(0.00)$ \\
\hline
\end{tabular}

Notes: As for Table 1(a).

The derivative of IEG equation with respect to $M$ shows that the effectiveness of money supply is conditional on the levels of $\mathrm{G}$, while the derivative 
of the equation with respect to $\mathrm{G}$ shows that the impact of $\mathrm{G}$ on IEG is conditional not only on the levels of $\mathrm{M}$ but also on $\mathrm{G}$ because $\mathrm{G}$ is non-linearly related to IEG. The $25^{\text {th }}, 50^{\text {th }}$ and $75^{\text {th }}$ percentiles of $\mathrm{G}$ and $\mathrm{M}$ are considered for analysis and the results are shown in Table $4 \mathrm{~b}$.

The results in Table $4 \mathrm{a}$ show that human capital, physical capital and institutional quality affect IEG positively and the coefficients are significant at $1 \%$ level. Investment in physical capital generates employment opportunities, while investment in human capital helps to increase the productivity of labourers and therefore increases employment opportunities for them. The institutional quality ensures proper implementation of policies without any loopholes. However, the impact of trade openness is significant in POLS and 2SLS models only and it negatively affects IEG because imports are greater than exports in developing countries that may hinder the growth of domestic industries.

The results in Table $4 \mathrm{~b}$ indicate that the role of money supply in promoting economic inclusiveness is positive and significant at all levels of government expenditure. However, at higher levels of government expenditure the effectiveness of money supply increases because here comes the role of money supply known as seigniorage.

Table 4c: Impact of government expenditures at different levels of M- using Table 4a

\begin{tabular}{|c|c|c|c|c|}
\hline M & POLS & FEM & REM & 2SLS \\
\hline \multicolumn{5}{|c|}{$\mathrm{G}=\mathrm{p} 25$} \\
\hline \multirow[t]{2}{*}{$\mathrm{P} 25=3.438$} & $0.255^{* * *} *$ & 0.090 & 0.095 & $0.428 * * *$ \\
\hline & $(0.00)$ & $(0.466)$ & $(0.44)$ & $(0.000)$ \\
\hline \multirow[t]{2}{*}{$\mathrm{P} 50=3.798$} & $0.260 * * *$ & 0.172 & 0.176 & $0.371^{* * *} *$ \\
\hline & $(0.00)$ & $(0.146)$ & $(0.125)$ & $(0.000)$ \\
\hline \multirow[t]{3}{*}{$\mathrm{P} 75=4.118$} & $0.269^{* * *} *$ & $0.245^{*}$ & $0.248^{*}$ & $0.330 * * *$ \\
\hline & $(0.00)$ & $(0.07)$ & $(0.055)$ & $(0.000)$ \\
\hline & & $\mathrm{G}=\mathrm{p} 50$ & & \\
\hline \multirow[t]{2}{*}{$\mathrm{P} 25=3.438$} & 0.030 & -0.051 & -0.046 & 0.118 \\
\hline & $(0.63)$ & $(0.70)$ & $(0.73)$ & $(0.117)$ \\
\hline \multirow[t]{2}{*}{$\mathrm{P} 50=3.798$} & 0.050 & 0.042 & 0.045 & $0.101 * *$ \\
\hline & $(0.31)$ & $(0.71)$ & $(0.675)$ & $(0.036)$ \\
\hline \multirow[t]{3}{*}{$\mathrm{P} 75=4.118$} & 0.069 & 0.125 & 0.126 & $0.087 * *$ \\
\hline & $(0.11)$ & $(0.33)$ & $(0.299)$ & $(0.044)$ \\
\hline & & $\mathrm{G}=\mathrm{p} 75$ & & \\
\hline \multirow[t]{2}{*}{$\mathrm{P} 25=3.438$} & $-0.200 * *$ & -2.041 & -0.200 & $-0.207^{*}$ \\
\hline & (0.04) & $(0.202)$ & $(0.213)$ & (0.064) \\
\hline \multirow[t]{2}{*}{$\mathrm{P} 50=3.798$} & $-0.171 * * *$ & -0.090 & -0.098 & $-0.190 * * *$ \\
\hline & $(0.00)$ & $(0.43)$ & $(0.405)$ & $(0.005)$ \\
\hline \multirow[t]{2}{*}{$\mathrm{P} 75=4.118$} & $-0.158 * * *$ & -0.004 & -0.069 & $-0.176^{* * *}$ \\
\hline & $(0.00)$ & $(0.975)$ & $(0.96)$ & $(0.002)$ \\
\hline
\end{tabular}

Notes: As for Table 1(a)

To finance high government expenditures, the government relies on tax revenue, debts and seigniorage. The first two may have negative consequences in 
the long run. Thus, the government prefers to finance its expenditures through seigniorage, which serves to stimulate economic activity (Chileshe and Kafula, 2015).

POLS and 2SLS results in Table 4c indicate that if government expenditure is at the $25^{\text {th }}$ percentile, there will be a positive impact of government expenditure at all levels of money supply. However, the results of FEM and REM models show that a low level of government expenditure fails to spur economic growth and doesn't improve economic inclusiveness, although the effect is positive at higher levels of money supply. When government expenditures are at a median level, it is not enough to affect economic growth, employment, and equality in income. But the 2SLS results show that the effect of government expenditures will be prominent provided high money supply.

However, OLS and 2SLS results show that a high level of government expenditure - at the $75^{\text {th }}$ percentile - affects economic growth negatively, because if money supply is already high, then there will be inflationary pressure on the economy. Aghevli and Khan (1977) suggest that inflationary pressures created by increased money supply cause government expenditures to rise faster than revenue, consequently causing a budget deficit, which in turn affects economic stability.

Table 5a displays the interactive role of tax revenue and money supply. The control variables, human capital, institutional quality, and investment in physical capital affect inclusiveness of economic growth positively whereas trade has a negative impact on dependent variable because it affects the income distributions adversely since a larger share of benefits of trade goes into the pockets of the rich class (Aradhyula, Rahman and Seenivasan, 2007). The coefficient values of money supply and tax revenue are positive and significant whereas their interactive terms are negative and significant in all models, however the ultimate impact of tax and money supply on inclusive economic growth can be assessed after looking into their total derivatives. The equation of the above model along with derivatives with respect to $\mathrm{M}$ and $\mathrm{TX}$ is as follows:

$$
\begin{gathered}
I E G_{i t}=\gamma_{0}+\gamma_{1} M_{i t}+\gamma_{2} T X_{i t}+\gamma_{3} M * T X_{i t}+\gamma_{4} Z_{i t}+u_{i t} \\
\frac{\partial I E G}{\partial M}=\gamma_{1}+\gamma_{3} T X_{i t} \\
\frac{\partial I E G}{\partial T X}=\gamma_{2}+\gamma_{3 .} M_{i t}
\end{gathered}
$$

The derivative of IEG with respect to $M$ shows that different levels of tax revenue influence the effectiveness of money supply. Similarly, the derivative of 
IEG with respect to TX illustrates that impact of tax on IEG is conditional on different levels of money supply. This study uses $25^{\text {th }}, 50^{\text {th }}$ and $75^{\text {th }}$ percentiles of $\mathrm{TX}$ and $\mathrm{M}$ for analysis and the results are shown in Table $5 \mathrm{~b}$.

Table 5a: Interactive impact of tax revenue and money supply

\begin{tabular}{|c|c|c|c|c|}
\hline Variables & POLS & FEM & REM & 2SLS \\
\hline \multirow[t]{2}{*}{$\mathrm{M}$} & $0.672 * * *$ & $0.315 * *$ & $0.325 * * *$ & $0.721 * * *$ \\
\hline & $(0.00)$ & $(0.011)$ & $(0.00)$ & $(0.00)$ \\
\hline \multirow[t]{2}{*}{$\mathrm{TX}$} & $0.765 * * *$ & 0.414 & $0.421 * *$ & $0.789^{* * *} *$ \\
\hline & $(0.00)$ & $(0.101)$ & $(0.09)$ & $(0.00)$ \\
\hline \multirow{2}{*}{$\mathrm{TX} * \mathrm{M}$} & $-0.132 * * *$ & -0.033 & -0.035 & $-0.141^{* * *}$ \\
\hline & $(0.00)$ & (0.59) & $(0.54)$ & $(0.00)$ \\
\hline \multirow[t]{2}{*}{ HCI } & $2.451 * * *$ & $2.489 * * *$ & $2.489 * * *$ & $2.360^{* * *}$ \\
\hline & $(0.00)$ & $(0.00)$ & $(0.00)$ & $(0.00)$ \\
\hline \multirow[t]{2}{*}{ IQ } & $0.332 * * *$ & $0.229 * *$ & $0.236 * *$ & $0.289 * * *$ \\
\hline & $(0.00)$ & $(0.03)$ & $(0.012)$ & $(0.00)$ \\
\hline \multirow[t]{2}{*}{ K } & $0.105^{*}$ & $0.223 * *$ & $0.222 * * *$ & $0.211^{* *}$ \\
\hline & $(0.07)$ & $(0.011)$ & $(0.00)$ & $(0.011)$ \\
\hline \multirow[t]{2}{*}{ Trade } & $-0.279 * * *$ & $-0.193 * *$ & $-0.201 * *$ & $-0.250 * * *$ \\
\hline & $(0.00)$ & $(0.04)$ & $(0.02)$ & $(0.00)$ \\
\hline \multirow{2}{*}{ Constant } & $-12.334 * * *$ & $-11.517 * * *$ & $-11.547 * * *$ & $-12.190 * * *$ \\
\hline & $(0.00)$ & $(0.00)$ & $(0.00)$ & $(0.00)$ \\
\hline No. of obs. & 1147 & 1147 & 1147 & 1096 \\
\hline No. of countries & 51 & 51 & 51 & 51 \\
\hline No. of instruments & & & & 7 \\
\hline R-Square & 0.689 & 0.541 & 0.682 & 0.709 \\
\hline F-stat & $274.52 * * *$ & $30.87 * * *$ & $239.96^{* * *} *$ & $285.56 * * *$ \\
\hline (p-value) & $(0.00)$ & $(0.00)$ & $(0.00)$ & $(0.00)$ \\
\hline \multirow{2}{*}{\multicolumn{2}{|c|}{ Bruesch-Pagan LM }} & & $98.22 * * *$ & \\
\hline & & & $(0.00)$ & \\
\hline \multirow[t]{2}{*}{ Hausman Test } & & 1.700 & & \\
\hline & & $(0.97)$ & & \\
\hline \multirow{2}{*}{\multicolumn{2}{|c|}{$\begin{array}{l}\text { Durbin Wu-Hausman } \\
\text { Test }\end{array}$}} & & & $3.553^{*}$ \\
\hline & & & & $(0.06)$ \\
\hline Hansen J Test & & & & $\begin{array}{c}0.372 \\
(0.541)\end{array}$ \\
\hline
\end{tabular}

Notes: As in Table 1, except that TX*M is the interaction of tax revenue and money supply.

Table 5b: Impact of money supply given TX Levels- using Table 5a

\begin{tabular}{lcccc}
\hline TX & POLS & FEM & REM & 2SLS \\
\hline P25 & $0.358^{* * *}$ & $0.236^{* *}$ & $0.242^{* *}$ & $0.368^{* * *}$ \\
& $(0.00)$ & $(0.019)$ & $(0.011)$ & $(0.000)$ \\
P50 & $0.320^{* * *}$ & $0.227^{* *}$ & $0.232^{* *}$ & $0.329^{* * *}$ \\
& $(0.00)$ & $(0.039)$ & $(0.024)$ & $(0.000)$ \\
P75 & $0.280^{* * *}$ & $0.218^{*}$ & $0.223^{* *}$ & $0.289^{* * *}$ \\
& $(0.00)$ & $(0.072)$ & $(0.049)$ & $(0.000)$ \\
\hline
\end{tabular}

Notes: As for Table 1b.

Table $5 \mathrm{~b}$ shows the impact of money supply given different levels of tax revenue. Results of all the models indicate that money supply has a positive and significant effect on economic inclusive growth that leads to the conclusion that an increase in money supply by reducing the interest rate causes an increase in output and employment levels. However, the value of the coefficient decreases with an 
increase in tax revenue due to the distortionary effect of high taxes. This result is in line with the study of Evans and Amey (1996), who are of the view that positive costs are associated with raising revenue through taxation, whereas financing through seigniorage results in efficiency gains.

The results of POLS and 2SLS models in Table 5c show a positive and significant impact of tax revenue on economic inclusive growth because it is used to finance public expenditure such as infrastructure and also helps to correct income distribution while FEM and REM show an insignificant impact of tax revenue. The coefficient value of tax revenue in both POLS and 2SLS decreases with an increase in the level of money supply. This result is consistent with the Olivera-Tanzi effect introduced by Olivera (1967) and Tanzi (1977), which suggests that high inflation induced by increased money supply causes a reduction in tax revenue.

Table 5c: Impact of tax revenue given M levels- using Table 5a

\begin{tabular}{lcccc} 
M & Pooled OLS & FEM & REM & 2SLS \\
\hline P25 & $0.310^{* * * *}$ & 0.300 & 0.302 & $0.281^{* * *}$ \\
& $(0.00)$ & $(0.214)$ & $(0.193)$ & $(0.000)$ \\
P50 & $0.260^{* * *}$ & 0.288 & 0.289 & $0.227 * * *$ \\
& $(0.00)$ & $(0.252)$ & $(0.227)$ & $(0.000)$ \\
P75 & $0.222^{* * *}$ & 0.271 & 0.278 & $0.180^{* * *}$ \\
& $(0.00)$ & $(0.288)$ & $(0.261)$ & $(0.000)$ \\
\hline
\end{tabular}

Notes: $*, * *, * * *$ are 1,5 and 10 percent level of significance respectively.

Overall, the above results suggest that fiscal and monetary policies can play a significant and positive role in making economic growth inclusive. Furthermore, these policy actions are not independent, that is, effectiveness of one policy depends on changes in the other policy and thus an effective and mutually consistent fiscal and monetary coordination is required to achieve the target of inclusive economic growth.

\section{Conclusion and policy implications}

Our results suggest that the expansionary monetary and fiscal policies that stimulate aggregate demand improve the output and employment situation in the developing region. At low levels of government spending, due to corresponding lower levels of aggregate demand, economies' growth will be slow paced. On the other hand, higher expenditures bring about a negative impact on inclusive economic growth because increased government consumption expenditures require huge financing through heavy taxation and local and external debts. It is therefore that there is an inverted U-shaped relationship between government size and efficiency.

Discussing the interactive role of fiscal and monetary policy, in an economic situation where government consumption expenditures are high, an 
increase in money supply leads to a decline in economic inclusive growth because the inflationary pressure created by an increased money supply causes government expenditures to increase faster than revenue. This causes a budget deficit, which affects economic stability and causes a reduction in output and employment. Regarding taxation, monetary policy is more effective at low levels of taxation because at high taxation, the distortionary effect may hinder growth. If a country is more focused towards economic inclusiveness, expansionary fiscal and monetary policies are effective. However, it is observed that high expenditures in developing countries, which lead to debt crises, not only directly affect economic inclusiveness but also reduce the effectiveness of monetary policy. Therefore, the governments in these countries should aim to cut their spending. Thus, an increase in the money supply given a moderate level of government expenditure is a favourable policy option. 


\section{References}

Adeleke, I. A., Uboh, V., \& Shobande, O. A. (2015). Monetary policy towards inclusive growth in Nigeria. The Nigerian Journal of Economics and Social Studies, 57(2), 313-337.

Afonso, A., Alves, J., \& Balhote, R. (2019). Interactions between monetary and fiscal policies. Journal of Applied Economics, 22(1), 132-151.

Aghevli, B. B., \& Khan, M. S. (1977). Inflationary finance and the dynamics of inflation: Indonesia, 1951-72. The American Economic Review, 67(3), 390403.

Alekhina, V., \& Ganelli, M. G. (2020). Determinants of Inclusive Growth in ASEAN. International Monetary Fund.

Aradhyula, S. V., Rahman, T., \& Seenivasan, K. (2007). Impact of international trade on income and income inequality. Proceedings of the American Agricultural Economics Association Annual Meeting, 1-43.

Armey, D. (1995). The Freedom Revolution: Why Big Government Failed, Why Freedom Works, and How We Will Rebuild America. Regnery Publishing.

Ayeh, J. K., \& Lin, S. (2011). Estimating tomorrow's tourist arrivals: Forecasting the demand for China's tourism using general-to-specific approach. Tourism Hospitality Research, 11(3), 197-206.

Barro, R. J. (1976). Rational expectations and the role of monetary policy. Journal of Monetary Economics, 2(1), 1-32.

Barro, R. J. (1990). Government spending in a simple model of endogenous growth. Journal of Political Economy, 98, 103-125.

Barro, R. J. (2000). Inequality and growth in a panel of countries. Journal of Economic Growth, 5(1), 5-32.

Becker, G. S. (1962). Investment in human capital: A theoretical analysis. The Journal of Political Economy, 70(5), 9-49.

Berg, A. G., \& Ostry, J. D. (2011). Equality and efficiency. Finance \& Development, 48(3), 12-15.

Chileshe, M. P., \& Kafula, L. (2015). The effects of fiscal policy on the conduct and transmission mechanism of monetary policy in Zambia. COMESA Monetary Institute, Nairobi: Kenya. 
Chongvilaivan, A. (2020). Openness and inclusive growth in South-East Asia. Achieving Inclusive Growth in the Asia Pacific, 87, 1-279.

Chu, K. Y., \& Hemming, R. (1991). Public Expenditure Handbook: A Guide to Public Policy Issues in Developing Countries. International Monetary Fund.

Ciccone, A., \& Jarociński, M. (2010). Determinants of economic growth: Will data tell? American Economic Journal, 2(4), 222-46.

Evans, J. L., \& Amey, M. C. (1996). Seigniorage and tax smoothing: Testing the extended tax-smoothing model. Journal of Macroeconomics, 18(1), 111125 .

Fleisher, B., Li, H., \& Zhao, M. Q. (2010). Human capital, economic growth, and regional inequality in China. Journal of Development Economics, 92(2), $215-231$.

Friedman, M., \& Meiselman, D. (1963). The relative stability of monetary velocity and the investment multiplier in the United States. Alfred P. Sloan School of MIT Working Paper.

Grosse, M., Harttgen, K., \& Klasen, S. (2008). Measuring pro-poor growth in nonincome dimensions. World Development, 36(6), 1021-1047.

Hajamini, M., \& Falahi, M. A. (2014). The nonlinear impact of government consumption expenditure on economic growth: Evidence from low and low-middle income countries. Cogent Economics \& Finance, 2(1), 1-15.

Hanke, S. H. (1997). How to establish monetary stability in Asia. Cato Journal, 17(3), 295-301.

Hendry, D. F. (1995). Dynamic Econometrics. Oxford University Press.

Hilbers, P. (2004). Interaction of monetary and fiscal policies: Why central bankers worry about government budgets. IMF Seminar on Current Development in Monetary and Financial Law.

Hoover, K. D., \& Perez, S. J. (1999). Data mining reconsidered: Encompassing and the general-to-specific approach to specification search. The Econometrics Journal, 2(2), 167-191.

Huang, Y., \& Quibria, M. G. (2013). The global partnership for inclusive growth. WIDER Working Paper, 2013/059, 1-25. 
Ikhide, S. I., \& Alawode, A. A. (1993). Financial sector reforms, macroeconomic instability and the order of economic liberalization: Evidence from Nigeria. AERC Research Paper, 112, 1-32.

Keskin, A. (2017). Income distribution and economic growth: A complementary cross country study to the Kuznets curve. Afyon Kocatepe Universitesi Sosyal Bilimler Dergisi, 19(2), 235-250.

Klasen, S. (2010). Measuring and monitoring inclusive growth: Multiple definitions, open questions, and some constructive proposals. $A D B$ Sustainable Development Working Paper, 12, 1-25.

Kuznets, S. (1955). Economic growth and income inequality. The American Economic Review, 45(1), 1-28.

Landau, D. (1983). Government expenditure and economic growth: A crosscountry study. Southern Economic Journal, 49(3), 783-792.

Leeper, E. M. (1991). Equilibria under 'active' and 'passive' monetary and fiscal policies. Journal of Monetary Economics, 27(1), 129-147.

Lin, J. Y., Monga, C., \& Standaert, S. (2019). The inclusive sustainable transformation index. Social Indicators Research, 143(1), 47-80.

Lucas Jr., R. E. (1972). Expectations and the neutrality of money. Journal of Economic Theory, 4(2), 103-124.

McKinley, T. (2010). Inclusive growth criteria and indicators. ADB Sustainable Development Working Paper, 14, 1-36.

Meschi, E., \& Vivarelli, M. (2009). Trade and income inequality in developing countries. World Development, 37(2), 287-302.

Mincer, J. (1981). Human capital and economic growth. National Bureau of Economic Research, 803, 1-28.

Mohammed, I. (2019). Estimating tourism import demand elasticities for four countries using the general-to-specific approach. Journal of Applied Business and Economics, 21(3), 65-76.

Musgrave, R. A. \& Musgrave, P. B. (2004). Public Finance in Theory and Practice ( $5^{\text {th }}$ Edition). Tata McGraw Hill.

Nirola, N., \& Sahu, S. (2019). The interactive impact of government size and quality of institutions on economic growth-evidence from the states of India. Heliyon, 5(3), 1-28. 
Ofoegbu, G. N., Akwu, D. O. \& Oliver, O. (2016). Empirical analysis of effect of tax revenue on economic development of Nigeria. International Journal of Asian Social Science, 6(10), 604-613.

Ogunmuyiwa, M. S., \& Ekone, A. F. (2010). Money supply-economic growth nexus in Nigeria. Journal of Social Sciences, 22(3), 199-204.

Okpe, I. I. (1998). Personal Income Tax in Nigeria. New Generation Books.

Ola, C. (2001). Income Tax Law and Practice in Nigeria (5 ${ }^{\text {th }}$ Edition). Ibadan: Dalag Prints and Park.

Olivera, J. H. G. (1967). Money, prices and fiscal lags: A note on the dynamics of inflation. Banca Nazionale del Lavoro Quarterly Review, 20(82), 258-267

Onoh, J. K. (2007). Dimensions of Nigeria's Monetary and Fiscal PoliciesDomestic and External. Astra Meridian Publishers.

Pérez-Moreno S., Martín-Fuentes N., \& Albert, JF. (2022). Rethinking Monetary Policy in the Framework of Inclusive and Sustainable Growth. In: Arestis P., \& Sawyer, M. (Edition) Economic Policies for Sustainability and Resilience. International Papers in Political Economy. Palgrave Macmillan, Cham. Available At: https://doi.org/10.1007/978-3-030-84288-8_8

Ram, R. (1986). Government size and economic growth: A new framework and some evidence from cross-section and time-series data. American Economic Review, 76, 191-203.

Ranieri, R., \& Ramos, R. A. (2013). After all, what is inclusive growth? International Policy Centre for Inclusive Growth, One pager, 188.

Ravallion, M., \& Chen, S., (1997). What can new survey data tell us about recent changes in distribution and poverty? World Bank Economic Review, 11(2), $357-82$.

Rauniyar, G., \& Kanbur, R. (2010). Inclusive growth and inclusive development: A review and synthesis of Asian Development Bank literature. Journal of the Asia Pacific Economy, 15(4), 455-469.

Romer, P. (1990). Are nonconvexities important for understanding growth? NBER Working Paper, 3271, 1-12.

Romer, C. D. \& Romer, R. H. (1998). Monetary policy and the well-being of the poor. NBER Working Paper, 6793, 1-62. 
Rubinson, R. (1977). Dependency, government revenue, and economic growth, 1955-1970, Studies in Comparative International Development, 12(2), 328.

Sachs, J. D., McArthur, J. W., Schmidt-Traub, G., Kruk, M., Bahadur, C., Faye, M., \& McCord, G. (2004). Ending Africa's poverty trap. Brookings Papers on Economic Activity, 35(1), 117-216.

Schultz, T. W. (1963). The Economic Value of Education. Columbia University Press.

Sargent, T. J., \& Wallace, N. (1984). Some Unpleasant Monetarist Arithmetic. Palgrave Macmillan: London.

Sen, A. (1992). On concepts and measure of poverty. Comercio Exterior, 42(4), 310-322.

Smith, A. (1776). An Inquiry into the Wealth of Nations. Strahan and Cadell: London.

Solow, R. M. (1956). A contribution to the theory of economic growth. The Quarterly Journal of Economics, 70(1), 65-94.

Sprinkel, B. W. (1963). Relative economic growth rates and fiscal-monetary policies. Journal of Political Economy, 71(2), 154-159.

Stuart, E. (2011). Making growth inclusive: Some lessons from countries and the literature. Oxfam Policy and Practice: Private Sector, 8(1), 89-131.

Taghizadeh-Hesary, F., Yoshino, N., \& Shimizu, S. (2018). The impact of monetary and tax policy on income inequality in Japan. $A D B$ Working Paper, 837, 1-22.

Tanzi, V. (1977). Inflation, lags in collection, and the real value of tax revenue. IMF Staff Papers, 24(1), 154-167.

Von-Hagen, J., \& Mundschenk, S. (2003). Fiscal and monetary policy coordination in EMU. International Journal of Finance \& Economics, 8(4), 279-295.

White, H., \& Anderson, E. (2001). Growth versus distribution: Does the pattern of growth matter? Development Policy Review, 19(3), 267-289.

World Bank (2009). What is Inclusive Growth? World Bank.

World Bank. (2020). Kyrgyz Republic Public Expenditure Review: Creating Fiscal Space for Inclusive Growth. Available At: https://doi.org/10.1596/35789 
Wyplosz, C. (1999). Economic policy coordination in EMU: Strategies and institutions. ZEI Policy Paper ,11, 1-25. 
Efficacy of Macroeconomic Policies to Achieve Inclusive Growth: Evidence from Developing Countries

\section{Appendix}

Table A1: List of countries

\begin{tabular}{llllllll}
\hline 1. & Algeria & 14. & Cote d'Ivoire & 27. & Israel & 40. & Peru \\
2. & Angola & 15. & Dominican Republic & 28. & Jamaica & 41. & Philippines \\
3. & Bangladesh & 16. & Ecuador & 29. & Korea Rep. & 42. & Senegal \\
4. & Bolivia & 17. & Egypt Arab Rep. & 30. & Malaysia & 43. & South Africa \\
5. & Botswana & 18. & El Salvador & 31. & Mexico & 44. & Sri Lanka \\
6. & Brazil & 19. & Ethiopia & 32. & Mongolia & 45. & Thailand \\
7. & Cameroon & 20. & Ghana & 33. & Morocco & 46. & Togo \\
8. & Chile & 21. & Guatemala & 34. & Mozambique & 47. & Tunisia \\
9. & China & 22. & Haiti & 35. & Namibia & 48. & Turkey \\
10. & Colombia & 23. & Honduras & 36. & Nicaragua & 49. & Uruguay \\
11. & Congo Dem. Rep. & 24. & India & 37. & Pakistan & 50. & Venezuela RB \\
12. & Congo Rep. & 25. & Indonesia & 38. & Panama & 51. & Zambia \\
13. & Costa Rica & 26. & Iran Islamic Rep. & 39. & Paraguay & & \\
\hline
\end{tabular}

